\title{
Pilot feasibility study of an emergency paediatric kit for intra-rectal quinine administration used by the personnel of community-based health care units in Senegal
}

\author{
Jean Louis A Ndiaye*1, Roger C Tine ${ }^{1}$, Babacar Faye ${ }^{1}$, El Hadj Lamine Dieye ${ }^{3}$, \\ Pape Amadou Diack ${ }^{3}$, Valérie Lameyre ${ }^{4}$, Oumar Gaye ${ }^{1}$ and \\ Husseyn Dembel Sow ${ }^{2}$
}

Address: ${ }^{1}$ Service de Parasitologie, Faculté de Médecine, Université Cheikh Anta DIOP de Dakar, Senegal, ${ }^{2}$ Hôpital d'Enfants Albert Royer, Center Hospitalier National Universitaire de Dakar Fann, Senegal, ${ }^{3}$ Ministère de la Santé et de la Prévention Médicale, Senegal and ${ }^{4}$ Impact Malaria, Sanofi-Aventis Group, Gentilly, France

Email: Jean Louis A Ndiaye* - jlndiaye@yahoo.com; Roger C Tine - rogertine@hotmail.com; Babacar Faye - bfaye67@yahoo.fr; El Hadj Lamine Dieye - deylamine@yahoo.fr; Pape Amadou Diack - padiack@ised.sn; Valérie Lameyre - valerie.lameyre@sanofi.aventis.com; Oumar Gaye - ogaye@refer.sn; Husseyn Dembel Sow - drdembelsow31@hotmail.com

* Corresponding author

Published: 15 November 2007

Malaria Journal 2007, 6:152 doi:10.1 186/1475-2875-6-152

This article is available from: http://www.malariajournal.com/content/6/I/152

(c) 2007 Ndiaye et al; licensee BioMed Central Ltd.

This is an Open Access article distributed under the terms of the Creative Commons Attribution License (http://creativecommons.org/licenses/by/2.0), which permits unrestricted use, distribution, and reproduction in any medium, provided the original work is properly cited.
Received: 3I May 2007

Accepted: 15 November 2007

\begin{abstract}
Background: Quinine injection is the reference treatment for malaria when oral administration is impossible. Quinine can also be administered by the intra-rectal route and, over the last ten years, a series of studies have been conducted in children to determine the ideal dose and dilution in the African situation. The aim of the present study was to evaluate the feasibility and usefulness of a kit for an immediate administration of quinine alkaloids (Quinimax ${ }^{\circledR}$ ) by community health workers, prior to transfer of the child to a more sophisticated health care establishment.
\end{abstract}

Methods: A prospective, open, descriptive community intervention study conducted in northern Senegal at six village Health Units in children fewer than ten years of age with non-per-os malaria. Controls were given the routine care prior to transfer to a Health Center, and cases were in addition administered Quinimax ${ }^{\circledR}(20 \mathrm{mg} / \mathrm{ml})$ via the intra-rectal route before transfer. Patients were followed through complete cure and parasitological tests were carried out on Days 0, 3 and 7.

Results: 134 patients (79 cases/55 controls) were recruited between November 2003 and May 2004 or October and November 2004. The two groups were comparable at inclusion. In the case group, oral drugs could be administered after a mean of 16.8 hours versus 33.6 hours in the control group. Time-to cure was shorter in cases than in controls. Complete parasite clearance was obtained in all patients by Day 7 . The kit was well accepted by all concerned and more than $80 \%$ of community health workers judged the kit easy to use.

Conclusion: The emergency paediatric kit is a useful tool in the management of malaria in children who cannot be treated orally. It is feasible and easy to use for health workers in community-based Health Units where, according to the WHO, nearly $80 \%$ of malarial morbidity and mortality occurs. 


\section{Background}

Malaria is the most serious parasitic disease throughout the tropics. According to the World Health Organization (WHO), more than two billion people are exposed, most of them living in Africa, the Americas and Southeast Asia. Malaria accounts for about $25 \%$ of all children's deaths in Africa [1]. Every year, more than 300 million people contract acute malaria and, of these new clinical cases, 1.7-2.4 million die (mostly children). In Africa, nearly $80 \%$ of children undergoing a severe malaria attack die before they reach any health care establishment, and only a minority is given any specific treatment [2].

The recommended treatment for severe malaria includes the injection, ideally intravenous, of quinine salts as soon as the first signs of severe malaria or danger manifest (WHO). However, community health structures possess neither the equipment nor the expertise to perform this type of procedure. The situation has to be improved so that all children who develop severe malaria can be treated as quickly as possible, beginning close to home. Intra-rectal administration could provide a solution to these problems. When oral administration is impossible, community-based workers in remote village health care units could administer treatment via this route, prior to transferring the patient to a more sophisticated establishment for comprehensive management.

A number of studies conducted in various countries in Africa (Niger, Burkina Faso, Madagascar and Senegal) have shown that intra-rectal administration of diluted quinine is an effective, safe form of treatment in the management of malaria in children [3-6].

In Senegal, the health care system in more remote areas is based on village-based health units run by community health workers with no formal medical or paramedical qualifications.

The aims of this study were (i) to study the feasibility of an emergency pediatric kit when used by community health workers; (ii)to evaluate the acceptance of this form of treatment; (iii) to evaluate the therapeutic benefit of immediate intra-rectal quinine administration in children with malaria who cannot be treated orally (non per os malaria).

\section{Methods}

\section{Study site}

The village of Savoigne is located thirty kilometers northeast of Saint Louis in the Senegal River Delta (Richard-Toll district). The climate is Sahelian with a long dry season between November and June, and a short rainy season from July to October.
Malaria is unstable in this region with great variability from one spot to another. The main vectors are Anopheles pharoensis and Anopheles gambiae s.l. $[7,8]$. The Plasmodium Index ranges from $5.20 \%$ to $38.50 \%$ in under- 15 year-olds [9]. According to clinical data collected in the Richard-Toll district in 2003, it is estimated that malaria accounts for $35 \%$ of all local pathology.

\section{Study design}

A prospective, descriptive community intervention study was conducted in children consulting community health workers in six villages around the Savoigne Health Center (Table 1). Most of the workers running the village-based units have only primary school education, and they are helped by local, unqualified midwives.

The six villages were randomized into two groups of three. The first group named a control group in which the children suffering from severe or non per os malaria were given conventional treatment before referral to the Health Center contains 3 villages. The second group of 3 villages named case group (or intervention group) in which the children received intra-rectal quinine before transfer. These 2 groups were made in order to describe the reference towards the health center whether or not a administration of quinine alkaloids was done to children with a non per os or severe malaria attacks in a same area at the same time. In order to investigate whether or not the supplementary treatment delayed referral, the research team did not get involved with the transfer of the sick children to the Health Center.

Included were all children of under 25 kilograms and/or 10 years of age presenting with a suspected malarial attack who could not be orally treated (severe or non per os malaria). Children in whom intra-rectal quinine administration was contra-indicated (because of diarrhoea or preexisting anal disease) were excluded from the case Group. Parental consent was obtained before enrolment.

After treatment at the village-based unit, all parents were told to take their sick children to the Health Center for

Table I: Health Units around the Savoigne Health Center

\begin{tabular}{lll}
\hline Health Unit & Distance from Health Center & Population \\
\hline Ndelle* & $4 \mathrm{~km}$ & 500 inhabitants \\
Barry & $6 \mathrm{~km}$ & 425 inhabitants \\
Ndiaye & $7 \mathrm{~km}$ & 1011 inhabitants \\
Ndioungue* & $8 \mathrm{~km}$ & 848 inhabitants \\
Mbodiène & $9.5 \mathrm{~km}$ & 912 inhabitants \\
Diagambal* & $12.5 \mathrm{~km}$ & 1086 inhabitants
\end{tabular}

* cases villages where intra rectal quinine was given 
confirmation of the diagnosis, curative treatment and follow-up.

This Study was approved by the Senegalese Ethics \& Scientific Committee on October 22, 2003.

\section{Procedures}

In the control villages, the children were cared for in line with national guidelines (paracetamol for high fever if possible and referral). In the case villages, the included children were also given an intra-rectal dose of 20 milligrams of quinine alkaloids per kilogram body weight (diluted in water to $30 \mathrm{mg} / \mathrm{ml}$ ). The paediatric kit contains;

- one phial of $4 \mathrm{ml}$ wich contains $500 \mathrm{mg}$ of quinine alkaloids composed by : $480 \mathrm{mg}$ of quinine $(770,25 \mathrm{mg}$ of quinine gluconate), $13,2 \mathrm{mg}$ of quinidine $(21,18 \mathrm{mg}$ of quinidine gluconate), $3,4 \mathrm{mg}$ of cinchonine $(4,24 \mathrm{mg}$ of cinchonine chlorhydrate) and 3,24 mg of cinchonidine $(4,03 \mathrm{mg}$ of cinchonidine chlorhydrate). This quinine is to be diluted into

- A bottle of 13,5 ml of purified water,

- a syringe graduated according to children bodyweight and age wich to administrate by rectal route the reconstituted solution by rectal route

The child was then monitored for thirty minutes. During this period, if any of the product was discharged, a further half-dose was administered before referral.

On arrival at the Health Center, a blood smear was performed to confirm the diagnosis and, for those with demonstrated malaria, treatment was administered in accordance with current National Malaria Control Programme recommendations (IV quinine or referral to the Regional Hospital). As soon as possible, the switch was made to an oral regimen with the currently recommended combination (SP + amodiaquine). At the Health Center, the patient's clinical condition was monitored and parasitological tests were performed every day until oral drugs could be administered. The patients were followed up through at least Day 7.

\section{Statistical analysis}

Two populations were analysed: Population 1 covering all eligible patients included at the village units who were referred to the Health Center; and Population 2 covering all eligible patients included at the village units who were found to have a confirmed parasitaemia on arrival at the Health Center.
The statistical analysis was performed using SAS software Version 8.2 (SAS Institute - Cary, NC). Descriptive analyses were carried out for each treatment group. The statistical significance threshold was set at 5\%. The analysis describe the time-to referral and clinical outcome in the intervention zone (case group with intra rectal quinine) versus the control group or non intervention zone.

\section{Results}

A total of 134 children (79 in case villages and 55 in control villages) were included in two phases, the first between November 2003 and May 2004, and then from October to November 2004.

\section{Description of the two groups at inclusion}

At inclusion, demographic characteristics were the same in the two groups (Table 2)

The time elapsed since appearance of the first symptoms was the same (mean $=52$ hours in both groups) and symptoms were similar - exceptions were the incidences of: hallucinations reported by $32.9 \%(\mathrm{n}=26)$ cases versus $45.5 \%(\mathrm{n}=25)$ controls; and agitation reported by $51.9 \%$ $(\mathrm{n}=41)$ cases and $70.9 \%(\mathrm{n}=39)$ controls (Table 3$)$.

\section{Feasibility and acceptance of the kit (79 Cases)}

After pre-calibrated dilution of the Quinimax ${ }^{\circledast}$ solution, the health worker withdrew the volume corresponding to

Table 2: Population details

\begin{tabular}{|c|c|c|c|}
\hline & $\begin{array}{c}\text { Cases } \\
N=79\end{array}$ & $\begin{array}{l}\text { Controls } \\
\mathrm{N}=55\end{array}$ & $\begin{array}{c}\text { Total } \\
N=134\end{array}$ \\
\hline \multicolumn{4}{|l|}{ Gender } \\
\hline Male & $43(54.4 \%)$ & $30(54.5 \%)$ & 73 (54.5\%) \\
\hline Female & $36(45.6 \%)$ & 25 (45.5\%) & $61(45.5 \%)$ \\
\hline \multicolumn{4}{|l|}{ Ethnic origin } \\
\hline Peulh & $9(11.4 \%)$ & $8(14.5 \%)$ & $17(12.7 \%)$ \\
\hline Woolof & $69(87.3 \%)$ & 46 (83.6\%) & $115(85.8 \%)$ \\
\hline Serere & $\mathrm{I}(\mathrm{I} .3 \%)$ & 0 & I (0.7\%) \\
\hline Diola & 0 & I (I.8\%) & I $(0.7 \%)$ \\
\hline \multicolumn{4}{|l|}{ Age (years) } \\
\hline Mean (SD) & $4.6(2.6)$ & $4.7(2.7)$ & $4.7(2.6)$ \\
\hline Median [QI; Q3] & $4.0[2.5 ; 6.0]$ & $4.5[2.7 ; 6.0]$ & $4.0[2.5 ; 6.0]$ \\
\hline (Minimum; Maximum) & $1 ; 10$ & $1 ; 10$ & $1 ; 10$ \\
\hline \multicolumn{4}{|l|}{ Weight (Kg) } \\
\hline Mean (SD) & $\begin{array}{c}\text { I3.85 (4.4I) } \\
\text { I3.00 }\end{array}$ & $\begin{array}{c}13.18(4.67) \\
12.00\end{array}$ & $\begin{array}{c}\text { I3.58 }(4.52) \\
13.00\end{array}$ \\
\hline Median [QI; Q3] & {$[10.20 ; 17.00]$} & {$[10.00 ; 16.00]$} & {$[10.00 ; 16.00]$} \\
\hline (Minimum; Maximum) & $7.5 ; 25.3$ & $4.0 ; 27.0$ & $4.0 ; 27.0$ \\
\hline \multicolumn{4}{|l|}{ Temperature $\left({ }^{\circ} \mathrm{C}\right)$} \\
\hline Mean (SD) & $\begin{array}{c}38.82(1.08) \\
39.20\end{array}$ & $\begin{array}{c}38.55(1.49) \\
38.90\end{array}$ & $\begin{array}{c}38.71(1.27) \\
39.05\end{array}$ \\
\hline Median [QI; Q3] & {$[38.40 ; 39.40]$} & {$[38.10 ; 39.50]$} & {$[38.40 ; 39.50]$} \\
\hline (Minimum; Maximum) & $34.9 ; 40.5$ & $32.7 ; 40.2$ & $32.7 ; 40.5$ \\
\hline
\end{tabular}


Table 3: Symptoms at inclusion

\begin{tabular}{|c|c|c|c|}
\hline Symptom & $\begin{array}{c}\text { Cases } \\
N=79\end{array}$ & $\begin{array}{c}\text { Controls } \\
N=55\end{array}$ & $\begin{array}{c}\text { Total } \\
N=134\end{array}$ \\
\hline \multicolumn{4}{|l|}{ Vomiting } \\
\hline Yes & 66 (83.5\%) & 39 (70.9\%) & 105 (78.4\%) \\
\hline Non & $13(16.5 \%)$ & $16(29.1 \%)$ & $29(21.6 \%)$ \\
\hline \multicolumn{4}{|c|}{ Convulsions } \\
\hline Yes & $3(3.8 \%)$ & 7 (I2.7\%) & 10 (7.5\%) \\
\hline Non & $76(96.2 \%)$ & $48(87.3 \%)$ & $124(92.5 \%)$ \\
\hline \multicolumn{4}{|c|}{ Loss of consciousness } \\
\hline Yes & $2(2.5 \%)$ & 4 (7.3\%) & $6(4.5 \%)$ \\
\hline Non & 77 (97.5\%) & $51(92.7 \%)$ & $128(95.5 \%)$ \\
\hline \multicolumn{4}{|l|}{ Agitation } \\
\hline Yes & $4 \mid$ (5I.9\%) & 39 (70.9\%) & 80 (59.7\%) \\
\hline No & $38(48.1 \%)$ & $16(29.1 \%)$ & $54(40.3 \%)$ \\
\hline \multicolumn{4}{|c|}{ Hallucinations } \\
\hline Yes & 26 (32.9\%) & 25 (45.5\%) & 51 (38.1\%) \\
\hline No & $53(67.1 \%)$ & $30(54.5 \%)$ & 83 (61.9\%) \\
\hline \multicolumn{4}{|c|}{ Bloody feces } \\
\hline Yes & $4(5.1 \%)$ & $2(3.6 \%)$ & $6(4.5 \%)$ \\
\hline No & 75 (94.9\%) & $53(96.4 \%)$ & $128(95.5 \%)$ \\
\hline \multicolumn{4}{|c|}{ Anal lesion } \\
\hline Yes & 0 & $2(3.6 \%)$ & $2(1.5 \%)$ \\
\hline No & 79 (100.0\%) & $53(96.4 \%)$ & I 32 (98.5\%) \\
\hline
\end{tabular}

the child's weight (using a syringe with kilogram graduations).

The administered dose was considered correct if the dose administered corresponded exactly to the child's weight: it was found to be correct in $93.6 \%$ of cases (and the deviations detected in the remaining cases were small)(Table 4).

Table 4: Dosing and ease of administration

\begin{tabular}{lc}
\hline & Village cases \\
\hline Correct dose & Yes $(93.6 \%)$ \\
& No (6.4\%) \\
\hline Ease of administration & Easy (77.2\%) \\
& Difficult (22.8\%) \\
\hline $\begin{array}{lc}\text { Quantity administered (kg eq.) } \\
\begin{array}{l}\text { Median (SD) } \\
\text { (Minimum; Q3] }\end{array}\end{array}$ \\
\hline
\end{tabular}

Administering the product was deemed easy in $77.2 \%$ of cases, and some of the difficulty of administration may be related the patients' reactions which were observed in $39 \%(\mathrm{n}=31)$, including agitation, crying out and tears (probably due to fear on introduction of the device). No parental reactions were reported. In $25 \%$ of cases, early discharge of the product within 30 minutes of the first dose necessitated the administration of a further half-dose of intra-rectal Quinimax ${ }^{\circledR}$.

\section{Time-to transfer from the Health Unit to the Health Center ( $n=134$ children)}

All 134 patients were referred to the Savoigne Health Center. The mean time-to transfer in this rural area was 4.40 hours $( \pm 11.07)$ in the case group, and 3.11 hours $( \pm$ $5.76)$ in the control group for the parents to bring children from their villahe to the health post.

\section{Therapeutic benefit}

This end point was evaluated by comparing the cases and the controls with a confirmed parasitaemia $(n=92)$ vis-àvis fever and parasitaemia over time, as well as the time intervals to obtain cure, to stop vomiting and to the switch to oral drugs.

\section{Time-to cure}

On Day 1, fewer cases than controls had fever $(71.4 \%$ versus $93.0 \%$ ). This difference persisted through Day 2 but had disappeared by Day 3 (Figure 1).

Vomiting stopped within one day in $97.8 \%$ cases and $79.5 \%$ controls (Table 5).

The mean number of days between the day of the consultation (and intra-rectal quinine administration at the village Health Unit for the cases) and the switch to oral drugs was significantly shorter in the case group than in the control group ( 0.7 days versus 1.4 days) (Table 6 ).

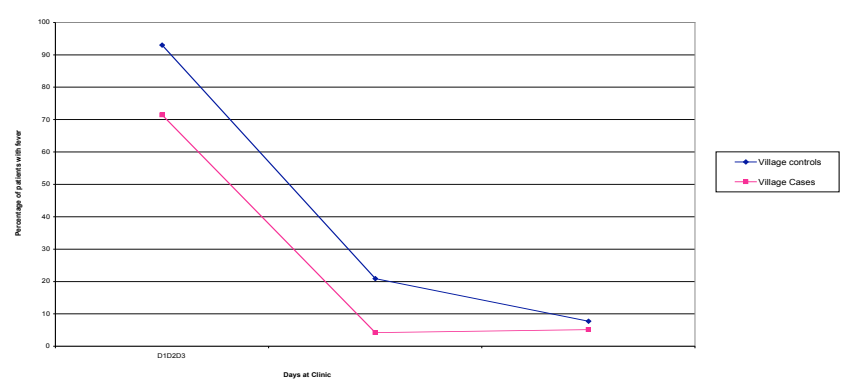

\section{Figure I}

Percentage of patients with fever. 
Table 5: Time-to stoppage of vomiting

\begin{tabular}{|c|c|c|c|}
\hline \multicolumn{4}{|c|}{ Number of days to the stoppage of vomiting } \\
\hline All included patients & Cases & Controls & $\begin{array}{c}\text { Total } \\
N=134\end{array}$ \\
\hline$\leq \mathrm{I}$ day & 71 (95.9\%) & $38(76.0 \%)$ & 109 (87.9\%) \\
\hline$>$ I day & $3(4.1 \%)$ & $12(24.0 \%)$ & $15(12.1 \%)$ \\
\hline patients with a confirmed parasitemia & $\begin{array}{c}\text { Cases } \\
N=49\end{array}$ & $\begin{array}{c}\text { Controls } \\
N=43\end{array}$ & $\begin{array}{l}\text { Total } \\
N=92\end{array}$ \\
\hline$\leq \mathrm{I}$ day & $45(97.8 \%)$ & $31(79.5 \%)$ & $76(89.4 \%)$ \\
\hline$>$ I day & I (2.2\%) & $8(20.5 \%)$ & $9(10.6 \%)$ \\
\hline Unknown & 3 & 4 & 7 \\
\hline
\end{tabular}

Similarly, the interval between consultation and cure was shorter in the case group than in the control group (1.9 days versus 2.2 days;).

\section{Parasite load}

On Day 3, blood smear were carried out in the 92 patients with parasitaemia on arrival at the Health Center. Parasite clearance was recorded in $74.4 \%$ of cases and $69.2 \%$ of controls (NS) (Figure 2).

Clearance was obtained in all patients by the end of the follow-up period.

\section{Safety of intrarectal Quinimax}

Safety data (symptoms) collected at the Health Center were analysed for all included patients.

On arrival at the Health Center, a difference was observed between the two groups in the mean number of feces in the preceding 24 hours: 1.2 in the case group versus 0.1 in the control group $(\mathrm{p}<0.0001)$.

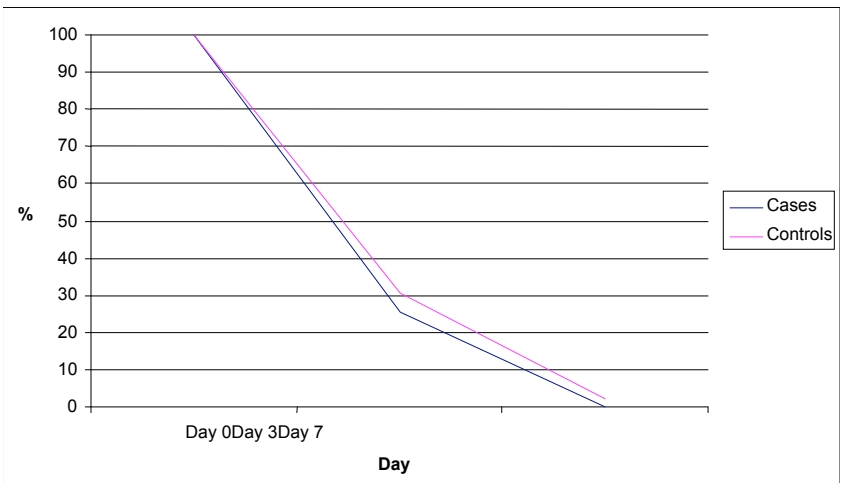

Figure 2

Percentage of patients with parasitemia from Day 0 to Day 7.
Of the village children who passed a stool on arrival at the Health Center (78 including six controls), eight cases passed liquid stools compared with three controls (Table 7).

In the following days (Day 2 through Day 5), the number of faeces per day in the two groups became comparable (Table 8).

\section{Serious Adverse Events}

In the course of this Study, one control child died after having been referred from the Health Center to Saint Louis Regional Hospital (the referral center for severe cases) with severe dehydration and clinical anaemia.

\section{Discussion}

This study was conducted to evaluate the feasibility and safety of an emergency paediatric kit when used by unqualified, community-based personnel, and to assess acceptance of the kit by local people.

The community-based health workers were observed to appreciate this novel therapeutic device.

Malaria was incorrectly diagnosed by community health workers in $22 \%$ of cases in this Study. The mean percentage of mistaken diagnoses has been estimated at $45 \%$ in certain health care structures in Senegal [10], and at $62 \%$ at the Muraz Center (Bobo Dioulasso/Burkina Faso) in

Table 6: Time-to switch to oral drugs

\begin{tabular}{lccc}
\hline Time-to switch (days) & Cases & Controls & Total \\
\hline $\mathrm{N}$ & 47 & 42 & 89 \\
Mean (SD) & $0.7(0.8)$ & $1.4(0.7)$ & $1.0(0.8)$ \\
Median [QI;Q3] & $1.0[0.0 ; 1.0]$ & $1.0[1.0 ; 2.0]$ & $1.0[1.0 ; 1.0]$ \\
Minimum;Maximum & $0 ; 5$ & $1 ; 4$ & $0 ; 5$ \\
\hline
\end{tabular}


Table 7: Number and nature of feces at inclusion and on arrival at the Health Center

\begin{tabular}{|c|c|c|}
\hline & Cases & Controls \\
\hline \multicolumn{3}{|l|}{ Number of feces in the preceding $24 h$} \\
\hline Mean (SD) & $0.6(0.9)$ & $1.0(1.0)$ \\
\hline Median [QI; Q3] & $0.0[0.0 ; 1.0]$ & $1.0[0.0 ; 2.0]$ \\
\hline (Minimum; Maximum) & $0 ; 4$ & $0 ; 4$ \\
\hline \multicolumn{3}{|c|}{$\begin{array}{l}\text { Number of feces on arrival at the Health } \\
\text { Center }\end{array}$} \\
\hline Mean (SD) & $1.2(0.9)$ & $0.1(0.4)$ \\
\hline Median [QI; Q3] & $1.0[1.0 ; 2.0]$ & $0.0[0.0 ; 0.0]$ \\
\hline (Minimum; Maximum) & $0 ; 5$ & $0 ; 2$ \\
\hline \multicolumn{3}{|l|}{$\begin{array}{l}\text { Nature of the feces on arrival at the } \\
\text { Health Center }\end{array}$} \\
\hline Diarrhea: thin or watery feces ( 3 or + ) & I (I.6\%) & 0 \\
\hline Thin or watery feces (fewer than 3) & 7 (II.3\%) & $3(50.0 \%)$ \\
\hline Soft, pale feces & $47(75.8 \%)$ & $3(50.0 \%)$ \\
\hline Normal stools & 7 (II.3\%) & 0 \\
\hline
\end{tabular}

the context of severe malaria [11]. This suggests that regular training and close supervision can improve the accuracy of malaria diagnosis by community health workers.

The administration of treatment prior to referral did not delay transfer of children to a more sophisticated health care facility for parenteral management.

The emergency paediatric kit is an effective tool in the early management of malaria in children who cannot be treated orally. Its use significantly cut down the period of time before the switch could be made to oral drugs, and accelerated clinical cure.

The percentage of children in whom early discharge of the administered product was observed was higher in this study $(25 \%)$ than those reported by Barennes $(12.9 \%)[2]$ and Ndiaye (12.1\%) [12]. Such discharge within thirty minutes will cut down the concentration of quinine in the blood but this can be compensated by administering another half-dose [13]. No particular adverse reactions were noted in patients who were given the second administration. Compression of the buttocks for five minutes after administration reduces the risk of discharge.

Table 8: Bloody feces before and after treatment

\begin{tabular}{lcc}
\hline Day & Cases & Controls \\
\hline Day 0: arrival at the Health Unit & $\mathbf{4}$ & $\mathbf{2}$ \\
Day 1: arrival at the Health Center & $\mathbf{2}$ & $\mathbf{2}$ \\
Day 2 to Day 5 & 6 & 3 \\
\hline
\end{tabular}

No serious adverse reaction to the product was observed in the course of this study, and none had been reported in either Madagascar, where intrarectal quinine administration has been common since 1985 [14] or in clinical trials in Niger, Togo, the Congo and Senegal $[15,12]$. In Niger, where a policy based on intrarectal quinine administration was officially adopted in 1994, Harouna reported a major anal abscess following this form of treatment in a patient who had previously experienced severe complications following intramuscular quinine injection; the abscess was cured with treatment [16].

\section{Conclusion}

The paediatric kit used in this study provides a useful therapeutic option for early, community-based malaria management in children who cannot be treated orally, until they can be transferred to a more sophisticated health care establishment for definitive care. It is feasible at the community level and simple to use. Its generalization should be accompanied by the training of community health workers on how to use it, as well as its specific indications and contraindications.

\section{Competing interests}

The author(s) declare that they have no competing interests.

\section{Authors' contributions}

JLAN: designed the study, collected data, and prepared the manuscript

RCT: collected data, and prepared the manuscript

$\mathrm{BF}$ : contributed in the preparation of the manuscript 
VL: designed the study and prepared the manuscript

ELD and PAD: collected data and participated in the design of the study

OG: designed the study and prepared the manuscript

HDS: designed the study and prepared the manuscript

All authors read and approved the final manuscript

\section{Acknowledgements}

We are grateful to the population of Savoigne, Saint Louis, Senegal who accepted to collaborate in this study. We thank the medical team of Savoigne's health post (especially Mr Cherif Seck the head Nurse), the Regional hospital of Saint Louis (especially the paediatrician Dr Marie Jesus), Dr Hubert Barennes who helped in the study preparation and technicians of the department of Parasitology of the Faculty of Medicine of the Dakar University, Souleymane Diedhiou, Bilo Diallo, Ousmane Ndiaye and Mamadou Diouf.

This study was supported by "Impact Malaria" from Sanofi Aventis group and the National Malaria Control Programme of Senegal.

\section{References}

I. WHO Malaria Expert Committee: Twentieth Report. WHO, Geneva 2000:74.

2. Breman JG, Egan A, Keusch GT: The intolerable burden of malaria: a new look at the numbers. Am J Trop Med Hyg 200I, 64(I-2 Suppl):iv-vii.

3. Barennes H, Kahiatani F, Clavier F, Meynard D, Njiifountawouo S, Barennes-Rasoanandrasana F, Amadou M, Soumana M, Mahamansani $A$, Granic $G$, Verdier F: La quinine intra-rectale, une alternative aux injections parentérales pour le traitement du paludisme du jeune enfant. Etude clinique, parasitologique et pharmacologique. Méd Trop 1995, 55:91S-94S.

4. Barennes H, Kahiatani F, Pussard E, Clavier F, Meynard D, Njiifountawouo S, Verdier F: Intra-rectal Quinimax ${ }^{\circledR}$ for the treatment of $P$. falciparum malaria in children in Niger: efficacy and pharmacokinetics. Trans $R$ Soc Trop Med Hyg 1995, 89:4I8-42I.

5. Barennes H, Mahaman Sani A, Kahia Tani F, Meda H, Khenin A: Tolérance de la quinine administrée en solution intra-rectale chez l'enfant en Afrique francophone. Méd Trop 1999, 52:4.

6. Barennes H, Pussard E, Mahamansani A, Clavier F, Kahiatani F, Granic $G$, Henzel D, Ravinet L, Verdier F: Efficacy and pharmacokinetics of a new intra-rectal quinine formulation in children with $P$. falciparum malaria. BrJ Clin Pharmacol 1996, 41:389-395.

7. Carrara GC, Petrarca V, Niang M, Coluzzi M: Anopheles pharoensis and transmission of Plasmodium falciparum in the Senegal River Delta, West Africa. Med Vet Entomol 1990, 4:42I-424.

8. Faye O, Ndir O, Gaye O, Bah IB, Dieng Th, Dieng Y, Diallo S, Diagne AK: Pratiques des personnels de santé et des populations en matière de diagnostic du paludisme et d'utilisation des antipaludéens à Dakar. Méd Trop 1995, 55:47-50.

9. Faye O, Fontenille D, Gaye O, Sy N, Molez JF, Konate L, Hebrard G, Herve JP, Trouillet J, Diallo S: Malaria and rice growing in the Senegal River delta (Senegal). Ann Soc Belg Med Trop 1995, 75:179-189.

10. Thiandoum R: Etude de morbidité et de la létalité palustre au niveau du centre hospitalier régional de Thiès (Sénégal). Thèse Pharmacie UCAD 2004, n69:.

11. Guiguemde Tr, Diallo AH, Khi Zerbo G: Clinical and parasitological aspects of severe malaria in adults in an urban area of Bobo-Dioulasso (Burkina Faso). Bull Soc Pathol Exot 2003, 96:99-100.

12. Ndiaye JLA, Ndao CT, Pussard E, Verdier F, Daff B, Gaye O, Le Hesran J-Y: La quinine administrée par voie intrarectale: une alternative intéressante aux injections intramusculaires dans le traitement des accès palustres simples de l'enfant en
Center de Santé périphérique au Sénégal. Bulletin Epidémiologique - Service National des Grandes Endémies 2000, n I 0: I-6.

13. Pussard E, Straczek C, Kaboré I, Bicaba B, Balima-Koussoubé T, Bourrée $\mathrm{P}$, Barennes $\mathrm{H}$ : Dose-dependent resorption of quinine after intrarectal administration to children with moderate falciparum malaria. Antimicrob Agents Chemother 2004, 48:4422-4426.

14. Barennes $\mathrm{H}$ : Is intrarectal quinine a safe alternative to intramuscular injectable quinine? Trop Doct 1994, 24:32-33.

15. Boureima Sh, Idrissa M: Evolution de la densité parasitaire chez les enfants paludéens après traitement à la quinine injectable diluée et administrée en intrarectale. Malaria and Infectious Diseases in Africa 1996, $\mathbf{n}^{\circ}$ 4:25-30.

16. Harouna Y, Gamatie Y, Gamatie S, Mounkaila H, Boureima M: A propos de deux complications chirurgicales graves de l'usage de la quinine intra-musculaire et intrarectale. Bull Soc Pathol Exot 2000, 93:328-330.
Publish with Biomed Central and every scientist can read your work free of charge

"BioMed Central will be the most significant development for disseminating the results of biomedical research in our lifetime. "

Sir Paul Nurse, Cancer Research UK

Your research papers will be:

- available free of charge to the entire biomedical community

- peer reviewed and published immediately upon acceptance

- cited in PubMed and archived on PubMed Central

- yours - you keep the copyright

Submit your manuscript here:

http://www.biomedcentral.com/info/publishing_adv.asp
BiolMedcentral 